\title{
THE STEADY-STATE SIMULINK MODEL OF THREE-PHASE ASYNCHRONOUS MOTOR USED ONBOARD A SHIP
}

\author{
Paul BURLACU 1 \\ Petrica POPOV ${ }^{2}$ \\ Florentiu DELIU 3 \\ Vasile DOBREF \\ Mitruț C. CARAIVAN 5 \\ ${ }^{1}$ Lecturer PhD eng.Naval Academy "Mircea cel Batran", Constanta, vasile.dobref@anmb.ro \\ 2Lecturer PhD Naval Academy "Mircea cel Batran", Constanta, florentiu.deliu@anmb.ro \\ ${ }^{3}$ Lecturer PhD eng.Naval Academy "Mircea cel Batran", Constanta, paul.burlacu@anmb.ro \\ ${ }^{4}$ Professor PhD eng. Naval Academy "Mircea cel Batran", Constanta, petrica.popov@anmb.ro \\ ${ }^{5} \mathrm{PhD}$ eng.Naval Academy "Mircea cel Batran", Constanta, caraivanmitrut@gmail.com
}

Abstract: A ship plant consisting in a three-phase AC asynchronous motor is well known onboard a ship. The steady-state numerical model helps to study the transitory phenomena's regarding power supply network.

Keywords: asynchronous motor; numerical model

\section{Introduction}

The three phase asynchronous motor also known as induction machine is a device that is used in almost all electrical applications. This is the reason for such device to be used in naval domain.

The study that is described in the article is based on a $160 \mathrm{Kw}$ three-phase asynchronous motor mathematical model which is implemented in Matlab Simulink. The Asynchronous Machine block implements a three-phase asynchronous machine (wound rotor, single squirrel-cage, or double squirrel-cage). It operates in either generator or motor mode. The state space model is based by the mode of operation that is dictated by the sign of the mechanical torque:

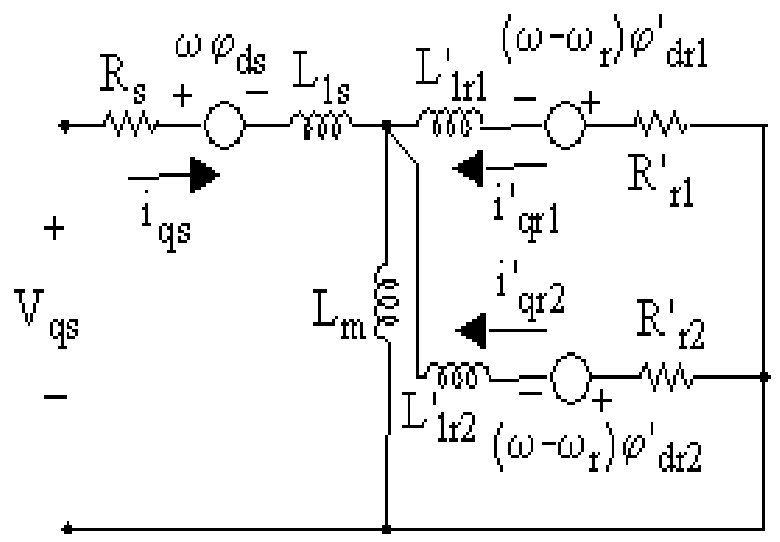

q axls
- If torque is positive, the electrical machine is a motor;

- If torque is negative, the electrical machine is a generator.

The mathematical model consists in two types of machines:

- Electrical System of the Wound-Rotor or Squirrel-Cage Machine;

- Electrical System of the Double SquirrelCage Machine.

For the study described in the article the wound-rotor system is used. The electrical scheme is presented in fig. 1.

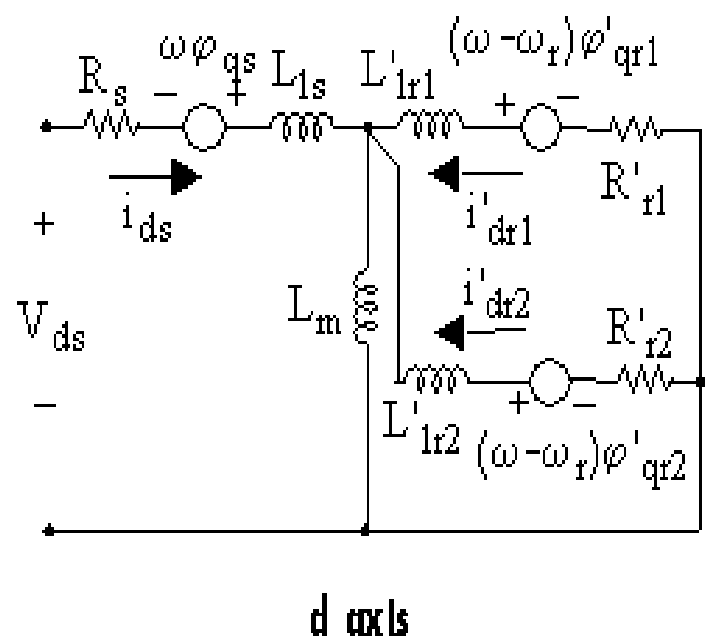

Figure 1 
"Mircea cel Batran" Naval Academy Scientific Bulletin, Volume XIX - 2016 - Issue 1

Published by "Mircea cel Batran" Naval Academy Press, Constanta, Romania // The journal is indexed in: PROQUEST / DOAJ / DRJI / JOURNAL INDEX / I2OR / SCIENCE LIBRARY INDEX / Google Scholar / Crossref /

Academic Keys / ROAD Open Access / OAJI / Academic Resources / Scientific Indexing Services / SCIPIO

$V_{\mathrm{qs}}=R_{\mathrm{s}} i_{\mathrm{qs}}+d \varphi_{\mathrm{qs}} / d t+\omega \varphi_{\mathrm{ds}}$

$V_{\mathrm{ds}}=R_{\mathrm{s}} i_{\mathrm{ds}}+d \varphi_{\mathrm{ds}} / d t-\omega \varphi_{\mathrm{qs}}$

$V_{\mathrm{qr}}^{\prime}=R_{\mathrm{r}}^{\prime} \dot{i}_{\mathrm{qr}}^{\prime}+d \varphi_{\mathrm{qr}}^{\prime} / d t+\left(\omega-\omega_{\mathrm{r}}\right) \varphi^{\prime}{ }_{\mathrm{dr}}$

$V_{\mathrm{dr}}^{\prime}=R_{\mathrm{r}}^{\prime} \dot{i}_{\mathrm{dr}}^{\prime}+d \varphi_{\mathrm{dr}}^{\prime} / d t-\left(\omega-\omega_{\mathrm{r}}\right) \varphi^{\prime}{ }_{\mathrm{qr}}$

$T_{\mathrm{e}}=1.5 p\left(\varphi \mathrm{ds} i_{\mathrm{qs}}-\varphi_{\mathrm{qs}} i_{\mathrm{ds}}\right)$

$V_{\mathrm{qs}}=R_{\mathrm{s}} i_{\mathrm{qs}}+d \varphi_{\mathrm{qs}} / d t+\omega \varphi_{\mathrm{ds}}$

$V_{\mathrm{ds}}=R_{\mathrm{s}} i_{\mathrm{ds}}+d \varphi_{\mathrm{ds}} / d t-\omega \varphi_{\mathrm{qs}}$

$0=R_{\mathrm{r} 1}^{\prime} i_{\mathrm{qr} 1}+d \varphi_{\mathrm{qr} 1}^{\prime} / d t+\left(\omega-\omega_{\mathrm{r}}\right) \varphi_{\mathrm{dr} 1}^{\prime}$

$0=R_{\mathrm{r} 1}^{\prime} i^{\prime}{ }_{\mathrm{dr} 1}+d \varphi^{\prime}{ }_{\mathrm{dr} 1} / d t-\left(\omega-\omega_{\mathrm{r}}\right) \varphi^{\prime}{ }_{\mathrm{qr} 1}$

$0=R_{\mathrm{r} 2}^{\prime} i_{\mathrm{qr} 2}^{\prime}+d \varphi_{\mathrm{qr} 2}^{\prime} / d t+\left(\omega-\omega_{\mathrm{r}}\right) \varphi^{\prime}{ }_{\mathrm{dr} 2}$

$0=R_{\mathrm{r} 2}^{\prime} i^{\prime}{ }_{\mathrm{dr} 2}+d \varphi^{\prime}{ }_{\mathrm{dr} 2} / d t-\left(\omega-\omega_{\mathrm{r}}\right) \varphi^{\prime}{ }_{\mathrm{qr} 2}$

$T_{\mathrm{e}}=1.5 p\left(\varphi_{\mathrm{ds}} i_{\mathrm{qs}}-\varphi_{\mathrm{qs}} i_{\mathrm{ds}}\right)$

Equations 1 refers to $q$ axis and equations 2 refers to $d$ axis. The electrical part of the machine is represented by a fourth-order state-space model, and the mechanical part by a second-order system. All electrical variables and parameters are referred to the stator, indicated by the prime signs in the following machine equations. All stator and rotor quantities are in the arbitrary twoaxis reference frame (dq frame). The subscripts used are defined in this table 1.

Table 1

\begin{tabular}{|l|l|}
\hline Subscript & Definition \\
\hline$d$ & d axis quantity \\
\hline$q$ & q axis quantity \\
\hline$r$ & $\begin{array}{l}\text { Rotor quantity (wound-rotor or } \\
\text { single-cage) }\end{array}$ \\
\hline$r 1$ & $\begin{array}{l}\text { Cage 1 rotor quantity (double- } \\
\text { cage) }\end{array}$ \\
\hline$r 2$ & $\begin{array}{l}\text { Cage 2 rotor quantity (double- } \\
\text { cage) }\end{array}$ \\
\hline s & Stator quantity \\
\hline $\mathrm{l}$ & Leakage inductance \\
\hline $\mathrm{m}$ & Magnetizing inductance \\
\hline
\end{tabular}

Table 2

\begin{tabular}{|l|l|}
\hline $\begin{array}{c}\text { Parameters } \\
\text { common to } \\
\text { all models }\end{array}$ & \multicolumn{1}{c|}{ Definition } \\
\hline $\mathrm{R}_{\mathrm{s}}, \mathrm{L}_{\mathrm{s}}$ & $\begin{array}{l}\text { Stator resistance and leakage } \\
\text { inductance }\end{array}$ \\
\hline $\mathrm{L}_{\mathrm{m}}$ & Magnetizing inductance \\
\hline $\mathrm{L}_{\mathrm{s}}$ & Total stator inductance \\
\hline $\mathrm{V}_{\mathrm{qs}}, \mathrm{I}_{\mathrm{q} s}$ & $\mathrm{q}$ axis stator voltage and current \\
\hline
\end{tabular}

\begin{tabular}{|c|c|}
\hline$V_{d s}, i_{d s}$ & $\mathrm{~d}$ axis stator voltage and current \\
\hline$\phi \mathrm{qs}, \phi \mathrm{ds}$ & Stator $\mathrm{q}$ and $\mathrm{d}$ axis fluxes \\
\hline$\omega_{\mathrm{m}}$ & Angular velocity of the rotor \\
\hline$\Theta_{m}$ & Rotor angular position \\
\hline $\mathrm{p}$ & Number of pole pairs \\
\hline$\omega_{r}$ & $\begin{array}{l}\text { Electrical angular velocity }\left(\omega_{m} \times\right. \\
\text { p) }\end{array}$ \\
\hline$\Theta_{\mathrm{r}}$ & $\begin{array}{l}\text { Electrical rotor angular position } \\
\left(\Theta_{m} \times p\right)\end{array}$ \\
\hline $\mathrm{T}_{\mathrm{e}}$ & Electromagnetic torque \\
\hline$T_{m}$ & Shaft mechanical torque \\
\hline $\mathrm{J}$ & $\begin{array}{l}\text { Combined rotor and load inertia } \\
\text { coefficient. Set to infinite to } \\
\text { simulate locked rotor. }\end{array}$ \\
\hline $\mathrm{H}$ & $\begin{array}{l}\text { Combined rotor and load inertia } \\
\text { constant. Set to infinite to } \\
\text { simulate locked rotor. }\end{array}$ \\
\hline $\mathrm{F}$ & $\begin{array}{l}\text { Combined rotor and load viscous } \\
\text { friction coefficient }\end{array}$ \\
\hline
\end{tabular}

Table 3

\begin{tabular}{|l|l|}
\hline $\begin{array}{c}\text { Parameters } \\
\text { specific to } \\
\text { single-cage or } \\
\text { wound rotor }\end{array}$ & \multicolumn{1}{|c|}{ Definition } \\
\hline $\mathrm{L}^{\prime} r$ & Total rotor inductance \\
\hline $\mathrm{R}^{\prime}{ }_{r}, \mathrm{~L}^{\prime} \mathrm{lr}$ & $\begin{array}{l}\text { Rotor resistance and leakage } \\
\text { inductance }\end{array}$ \\
\hline $\mathrm{V}_{\mathrm{q}}^{\mathrm{q}}, \mathrm{i}^{\prime} \mathrm{qr}$ & $\mathrm{q}$ axis rotor voltage and current \\
\hline $\mathrm{V}_{\mathrm{dr}}, \mathrm{i}^{\prime} \mathrm{dr}$ & $\mathrm{d}$ axis rotor voltage and current \\
\hline$\phi^{\prime} \mathrm{qr}, \phi^{\prime} \mathrm{dr}$ & Rotor q and d axis fluxes \\
\hline
\end{tabular}

\section{Mathematical model description}

The performances of the three-phase asynchronous motor that is used onboard of the 8200 tdw cargo ship will be presented starting from this point. The main characteristics for the electrical machine are:

- Voltage: $400 \mathrm{~V} \mathrm{AC}$;

- Frequency: 50Hz;

- Rated power: $160 \mathrm{Kw}$;

- 1500 RPM;

- Stator resistance: $0.01379 \mathrm{ohm}$;

- Rotor resistance: 0.007728 ohm;

- Stator inductance: $0.000152 \mathrm{H}$;

- Rotor inductance: $0.000152 \mathrm{H}$;

- Mutual inductance: $0.00769 \mathrm{H}$;

- Inertia: $2.9 \mathrm{~J}$;

- Pole number: 2.

\section{The Simulink model description}

The model that is implemented in matlab Simulink is presented in figure 2 and 3. 
"Mircea cel Batran" Naval Academy Scientific Bulletin, Volume XIX - 2016 - Issue 1 Published by "Mircea cel Batran" Naval Academy Press, Constanta, Romania // The journal is indexed in: PROQUEST / DOAJ / DRJI / JOURNAL INDEX / I2OR / SCIENCE LIBRARY INDEX / Google Scholar / Crossref / Academic Keys / ROAD Open Access / OAJI / Academic Resources / Scientific Indexing Services / SCIPIO

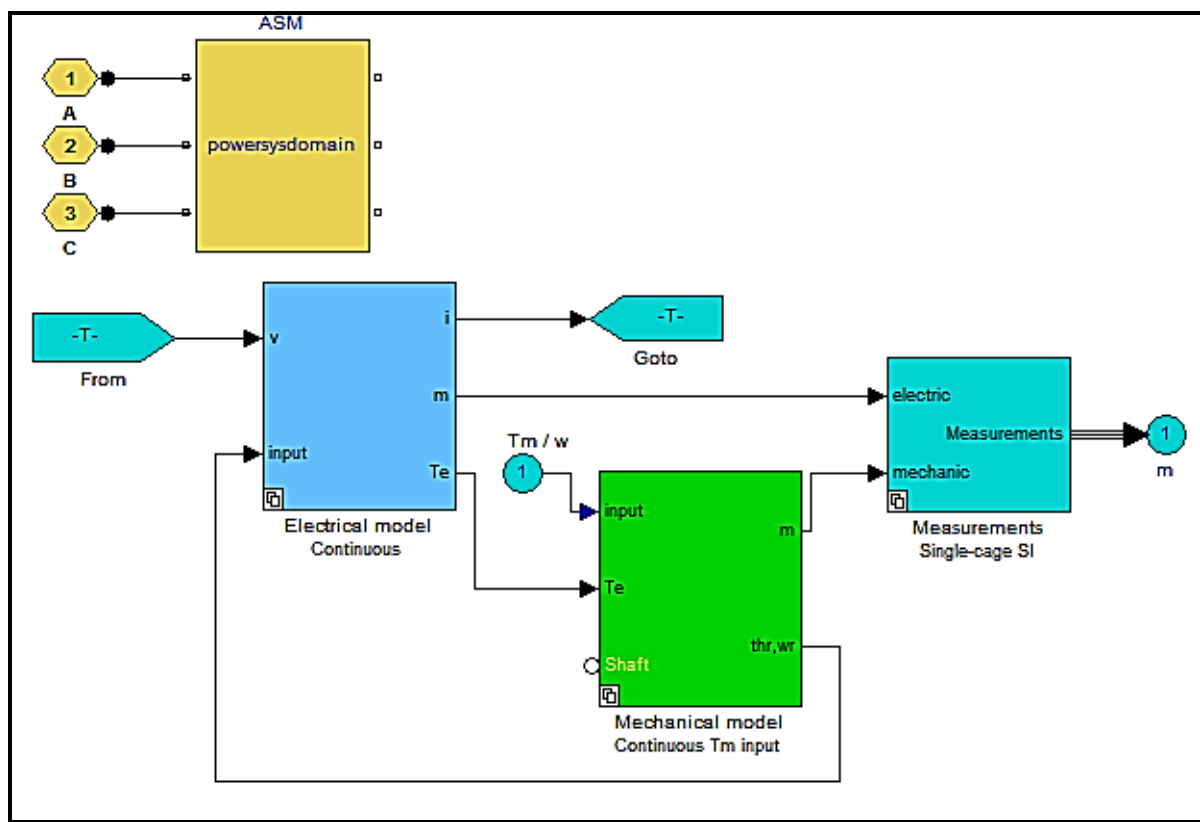

Figure 2

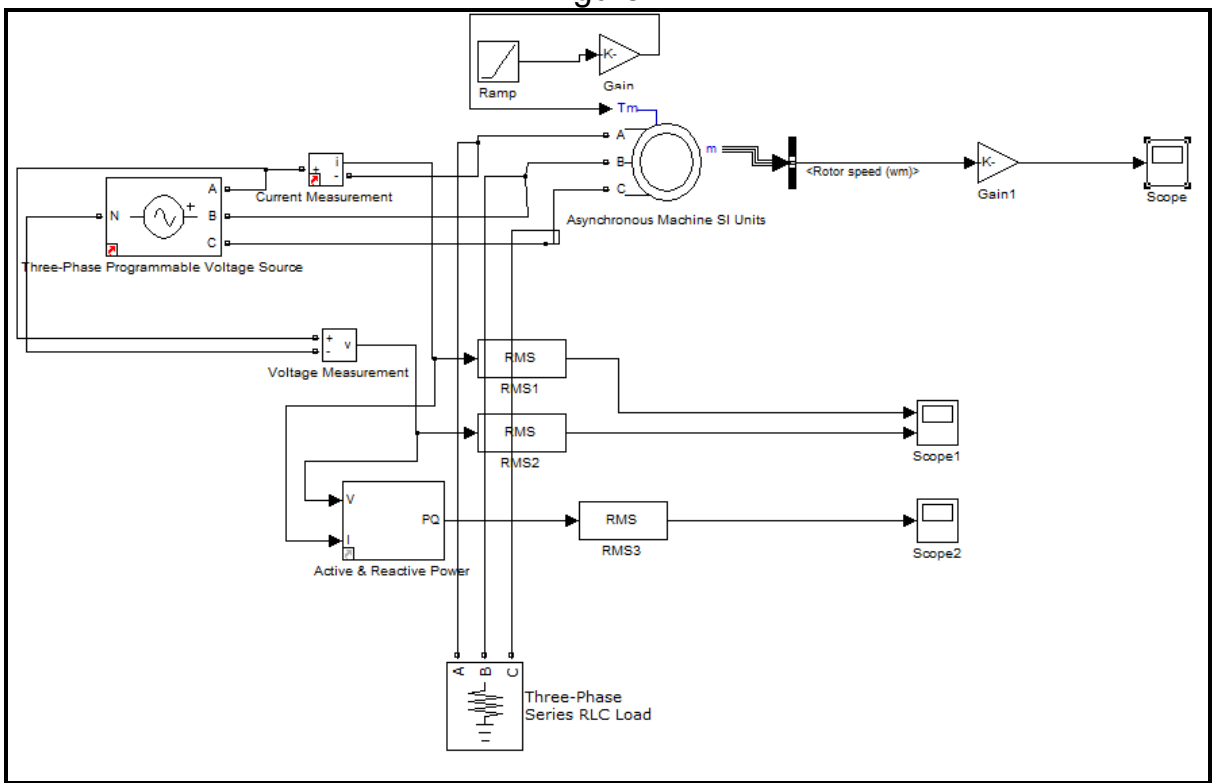

Figure 3

The simulation results are presented in the next graphics.

Current and voltage values: 
"Mircea cel Batran" Naval Academy Scientific Bulletin, Volume XIX - 2016 - Issue 1 Published by "Mircea cel Batran" Naval Academy Press, Constanta, Romania // The journal is indexed in: PROQUEST / DOAJ / DRJI / JOURNAL INDEX / I2OR / SCIENCE LIBRARY INDEX / Google Scholar / Crossref / Academic Keys / ROAD Open Access / OAJI / Academic Resources / Scientific Indexing Services / SCIPIO

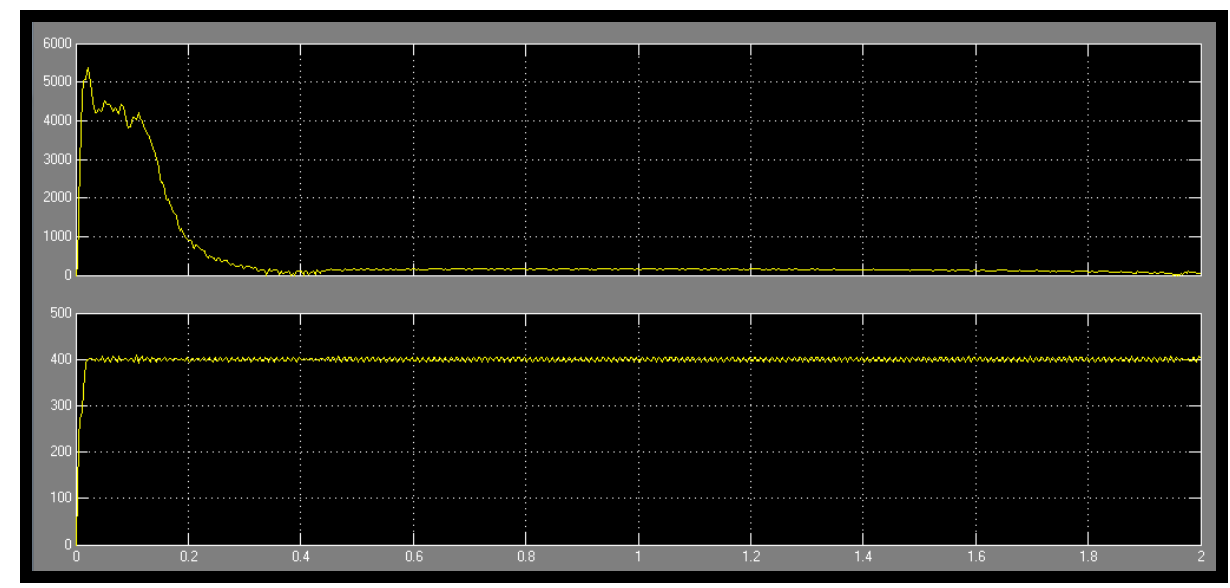

Figure 4

Active and reactive power values:

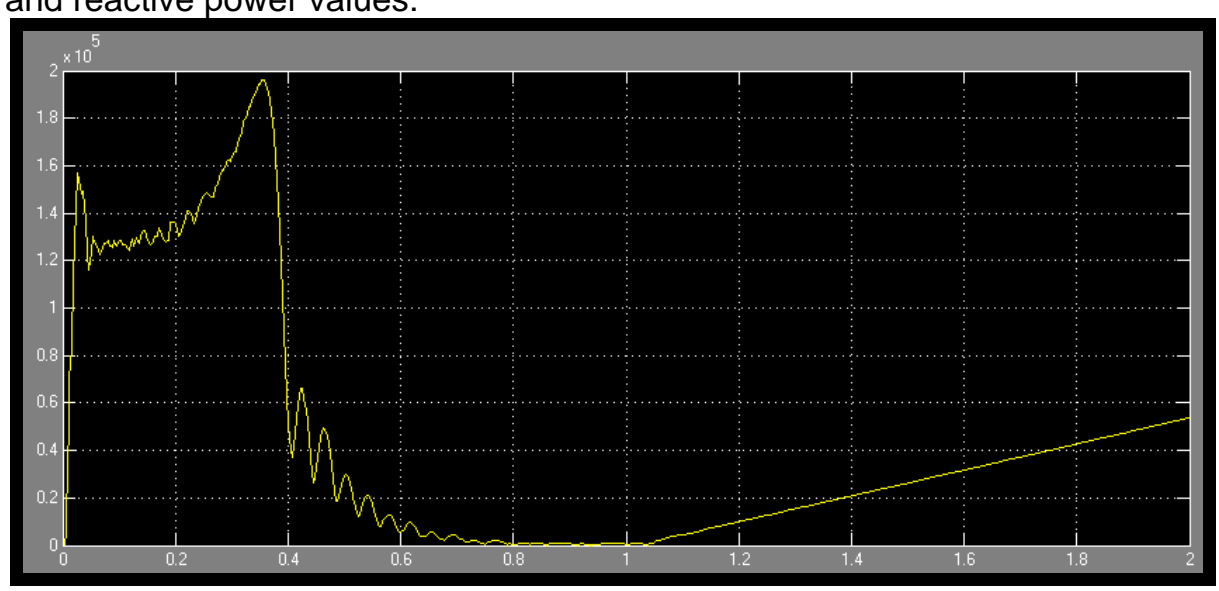

Figure 5

\section{CONCLUSION}

The mathematical model consists from two parts: electrical model and mechanical model. Both model are simulated in the Matlab Simulink .

The results presented in these two graphs shows that the $160 \mathrm{Kw}$ three-phase asynchronous motor is well fitted for naval purposes. The time response is minimum so transitory phenomena's could not affect the equipment's during period of functioning.

\section{BIBLIOGRAPHY}

[1] Popescu M., Induction Motor Modelling for Vector Control Purposes, Helsinki University of Technology, Laboratory of Electromechanics, Report, Espoo 2000.

[2] Krause, P.C., O. Wasynczuk, and S.D. Sudhoff, Analysis of Electric Machinery, IEEE ${ }^{\circledR}$ Press, 2002.

[3] Mohan, N., T.M. Undeland, and W.P. Robbins, Power Electronics: Converters, Applications, and Design, John Wiley \& Sons, Inc., New York, 1995, Section 8.4.1. 